\title{
PENERAPAN MODEL PEMBELAJARAN TSTS UNTUK MENINGKATKAN AKTIVITAS DAN HASIL BELAJAR SISWA
}

\author{
Magfirotul Mufida, Sholahuddin Al Ayubi, Tri Novita Irawati \\ magfirotul13@gmail.com \\ Universitas Islam Jember
}

\begin{abstract}
Abstrak
Penelitian ini bertujuan untuk meningkatkan aktivitas dan hasil belajar siswa melalui model pembelajaran Two Stay Two Stray (TSTS). Jenis penelitian ini adalah penelitian tindakan kelas (PTK). Subyek penelitian ini adalah siswa kelas VIII SMP Nusantara berjumlah 17 orang. Metode pengumpulan data yang digunakan adalah metode tes, observasi, dan dokumentasi. Penelitian ini dilakukan dalam dua siklus yaitu siklus I dan siklus II. Hasil penelitian dapat dilihat dari indikator keberhasilan siklus, siklus I untuk aktivitas belajar siswa sebesar $72 \%$ dan siklus II sebesar $75 \%$. Sedangkan hasil belajar siswa pada siklus I sebesar $71 \%$ dan siklus II sebesar $85 \%$. Dari indikator keberhasilan tersebut, disimpulkan bahwa penerapan model pembelajaran kooperatif tipe Two Stay Two Stray (TSTS) dapat meningkatkan aktivitas dan hasil belajar siswa
\end{abstract}

Kata Kunci: TSTS, aktivitas belajar, hasil belajar

\begin{abstract}
Abstrack
This aims of the research is to increase student activity and learning outcomes througha learning model Two Stay Two Stray (TSTS). Type of research is a classroom action research (CAR). The subject of this research is 17 students of class VIII SMP Nusantara. The data collection methods are using test methods, observation, and documentation. This research was conducted in two cycles, namely cycle I and cycle II. The results of the research can be seen from indicators of the sucsess of the cycle, the first cycle of student learning activities is $72 \%$ and the second cycle is $75 \%$. While student learning outcomes in the first cycle was $71 \%$ and the second cycle was $85 \%$. From these indicators of sucsess, it is concluded that the application of cooperative learning model with two stay two stray (TSTS) tipe can increase student activity and learning outcomes.
\end{abstract}

Keywords: TSTS, learning activity, learning outcomes 


\section{Magfirotul Mufida, Sholahuddin Al Ayubi, dan Tri Novita Irawati \\ E ISSN 2615-0697 dan P ISSN 2622-8149 \\ $108-114$}

\section{PENDAHULUAN}

UU No. 20 tahun 2003 menyatakan bahwa pendidikan adalah usaha sadar dan terencana untuk mewujudkan suasana belajar dan proses pembelajaran agar peserta didik secara aktif mengembangkan potensi dirinya untuk memiliki kekuatan spiritual keagamaan, pengendalian diri, kepribadian, kecerdasan, ahlak mulia, serta keterampilan yang diperlukan dirinya, masyarakat, bangsa, dan Negara. Oleh karena itu tujuan pendidikan nasional adalah untuk mencerdaskan kehidupan bangsa melalui pengembangan potensi siswa akan menjadi manusia yang beriman dan bertakwa kepada Tuhan Yang Maha Esa, berakhlak mulia, sehat, berilmu, cakap, kreatif, mandiri, dan menjadi warga negara yang demokratis serta bertanggung jawab. Salah satu mata pelajaran pada tingkat SMP adalah pembelajaran matematika. Berdasarkan tujuan pendidikan nasional tersebut, tidak sesuai dengan hasil wawancara yang dilakukan dengan guru matematika bahwasanya aktivitas siswa masih kurang sehingga hasil belajar juga rendah. Hasil wawancara pada siswa juga menunjukkan bahwa siswa kurang tertarik dengan pembelajaran matematika dikarenakan mereka merasa bosan dan kesulitan menjawab soal soal yang diberikan. Sehingga mengakibatkan aktivitas dan hasil belajar siswa rendah. Maka perlu dikembangkan model pembelajaran yang dapat meningkatkan aktivitas dan hasil belajar siswa. Dari permasalahan tersebut salah satu alternatif model pembelajaran dalam K13 adalah model pembelaaran Cooperative Learning. Model ini juga biasa disebut model pembelajaran gotong royong. Sifat pembelajaran Cooperative Learning tidak sama dengan pembelajar kelompok atau pembelajar bekerja sama biasa. Salah satu model Cooperatif Learning adalah TSTS (Two stay two stray). Model pembelajaran TSTS merupakan model pembelajaran kooperatif untuk pengelompokan siswa agar mampu berinteraksi dengan siswa lain dalam satu kelompok untuk menyelesaikan permasalahan dan tanggung jawab atas pembelajaran individu anggota. Kelebihan model pembelajaran ini adalah dapat diterapkan pada semua kelas/tingkat, kecenderungan siswa menjadi lebih bermakna dan dapat membantu meningkatkan aktivitas dan hasil belajar siswa menurut Lie (2010). Huda (2011) berpendapat sama yaitu model cooperative learning tipe TSTS ini dapat diterapkan untuk semua mata pelajaran dan tingkatan 


\section{Magfirotul Mufida, Sholahuddin Al Ayubi, dan Tri Novita Irawati \\ E ISSN 2615-0697 dan P ISSN 2622-8149 \\ $108-114$}

umur, serta memungkinkan setiap kelompok untuk saling berbagai informasi dengan kelompok kelompok lain. Hal ini dilakukan dengan cara saling mengunjungi atau bertamu antar kelompok untuk membagi informasi. Selain itu menurut Maerif (2012) TSTS adalah suatu model pembelajaran kooperatif yang memberikan kesempatan kepada kelompok membagikan hasil dan informasi kepada kelompok lain. Hal ini dilakukan karena banyak kegitan belajar mengajar yang yang diwarnai dengan kegiatan-kegiatan individu. Dengan tujuan mengarahkan siswa untuk aktif, baik berdiskusi, tanya jawab, mencari jawaban, menjelaskan dan juga menyimak materi yang dijelaskan oleh teman.

Berdasarkan latar belakang, masalah yang dihadapi siswa dan solusi yang di tawarkan peneliti tertarik melakukan penelitian dengan judul "Penerapan Model Pembelajaran TSTS Untuk Meningkatkan Aktivitas dan Hasil Belajar Siswa". Aktivitas belajar sendiri menurut Yusfy (2011) “Aktivitas adalah kegiatan. Jadi aktivitas belajar adalah kegiatan-kegiatan siswa yang menunjang keberhasilan belajar". Keberhasilan kegiatan pembelajaran ditentukan oleh kegiatan interaksi dalam pembelajaran tersebut. Semakin aktif siswa selama pembelajaran, semakin banyak pula pengalaman belajar yang akan diperoleh siswa dan tujuan pembelajaran akan tercapai. Sedangkan menurut Sardiman (2011) "Dalam belajar sangatlah diperlukan adanya aktivitas, tanpa adanya aktivitas belajar itu tidak mungkin berlangsung dengan baik karena pada prinsipnya belajar adalah berbuat untuk mengubah tingkah laku menjadi melakukan tindakan/aktivitas". Sedangkan hasil belajar menurut Mulyono (2003) Hasil belajar adalah kemampuan yang diperoleh anak setelah melalui kegiatan belajar. Belajar itu sendiri merupakan suatu proses dari seseorang yang berusaha untuk memproleh suatu bentuk perubahan prilaku yang relative menetap. Hamalik (2004) juga berpendapat hasil dan bukti belajar adalah adanya perubahan tingkah laku. Bukti bahwa seseorang telah belajar ialah terjadinya perubahan tingkah laku pada orang tersebut, misalnya dari tidak tahu menjadi tahu, dan dari tidak mengerti menjadi mengerti, hasil belajar akan tampak pada setiap perubahan pada aspek-aspek: pengetahuan, pengertian, kebiasaan, keterampilan, emosional, budi pekerti dan sikap. Dalam ilmu matematika Lingkaran sendiri adalah sebuah bangun datar dengan jari-jari sebesar satu. Lingkaran ini khususnya digunakan di 


\section{Magfirotul Mufida, Sholahuddin Al Ayubi, dan Tri Novita Irawati \\ E ISSN 2615-0697 dan P ISSN 2622-8149 \\ $108-114$}

dalam ilmu trigonometri. Lingkaran sering digunakan dalam kehidupan seharihari, kamu tentu sering menggunakan benda-benda yang berbentuk lingkaran, seperti uang logam, ban sepeda, kepingan $\mathrm{CD}$, dan sebagainya.

\section{METODE}

Jenis penelitian yang digunakan adalah PTK (penelitian tindakan kelas). PTK adalah sebuah bentuk kegiatan refleksi diri yang dilakukan oleh para pelaku pendidikan dalam suatu situasi kependidikan untuk memperbaiki rasionalitas dan keadialan tentang praktik-praktik kependidikan mereka, pemahaman mereka tentang praktik-praktik tersebut dan situasi dimana praktik-praktik tersebut dilaksanakan. Dimana peneliti adalah sebagai pemberi tindakan dan siswa kelas VIII SMP Nusantara tahun ajaran 2019/2020. Ketuntasan kriteria penelitian ini adalah jika 1) Hasil belajar siswa perorangan dikatakan meningkat apabila hasil dari siklus I dan siklus II terjadi peningkatan dengan kriteria ketuntasan ( KKM ) $\geq 75$ dari skor maksimal 100. 2) Persentase hasil belajar siswa dikatakan meningkat apabila dari siklus I ke siklus II terjadi peningkatan dengan kriteria minimal $75 \%$ dari presentase maksimal 100\%. 3) Persentase aktivitas belajar siswa dikatakan meningkat apabila dari siklus I ke siklus II terjadi peningkatan dengan kriteria minimal $75 \%$ dari presentase maksimal $100 \%$. Penelitian ini dilakukan dalam dua siklus, pada setiap siklus terdapat perencanaan, pelaksanaan tindakan, pelaksanaan observasi, dan refleksi. Selanjutnyan metode pengumpulan data pada penelitian ini menggunakan metode wawancara, tes, observasi, dan dokumentasi. Data yang diperoleh dalam penelitian ini dianalisis dengan langkahlangkah berikut:

1) Data tes hasil belajar dianalisis dengan cara dihitung dengan rumus berikut

Ketuntasan Individual $=\frac{\text { jumlsh perolehan }}{\text { jumlah maksimal }} \times 100 \%$

Ketuntasan Klasikal $=\frac{\text { jumlsh siswa yang tuntas }}{\text { jumlah siswa seluruhnya }} \times 100 \%$

Sumber : Departemen pendidikan nasional 2009.

2) Data hasil observasi aktivitas siswa didapat dengan menentukan presentase rata-rata dengan rumus sebagai berikut $: x=\frac{\mathrm{n}}{\mathrm{N}} \times 100 \%$ 
Keterangan :

$\mathrm{x}=$ Nilai rata-rata aktivitas siswa

$\mathrm{n}=$ Jumlah skor yang diperoleh siswa

$\mathrm{N}=$ Skor maksimal yang diperoleh siswa

Tabel 1.Kriteria ketuntasan Penilaian

\begin{tabular}{cc}
\hline Presentase & Kriteria \\
\hline $86 \%-100 \%$ & Sangat Baik \\
$75 \%-85 \%$ & Baik \\
$65 \%-74 \%$ & Cukup \\
$43 \%-64 \%$ & Kurang \\
$<42 \%$ & Sangat kurang \\
\hline
\end{tabular}

\section{HASIL DAN PEMBAHASAN}

Pembahasan hasil penelitian ini akan menguraikan beberapa hasil penelitian yang dianggap penting dalam meningkatkan hasil belajar siswa kelas VIII SMP Nusantara pada materi lingkaran. Hasil belajar siswa dari pembelajaran lingkaran ini yaitu berupa pemahamannya terhadap unsur-unsur lingkaran, keliling lingkaran, luas lingkaran, hubungan sudut pusat, panjang busur, luas juring dan kemampuan mereka dalam menyelesaikan soal yang berhubungan dengan lingkaran. Pembahasan hasil penelitian ini berdasarkan paparan data, hasil wawancara, hasil observasi,dan hasil tes.

Berdasarkan hasil penelitian, peneliti telah melaksanakan proses pembelajaran lingkaran dengan baik dan siswa telah melaksanakan kegiatan sesuai dengan yang diharapkan oleh rencana pelaksanaan pembelajaran. Pada awal pembelajaran, siswa sudah bisa memahami dan menunjukkan tentang apa saja unsur-unsur lingkaran. Dengan bekal materi yang sudah dimiliki siswa tersebut peneliti dapat dengan mudah meningkatkan rasa percaya diri siswa dan dengan mudah dapat menanamkan konsep lingkaran. Setelah dilakukan pembelajaran dengan metode TSTS dengan dua siklus, siswa dapat memahami materi lingkaran dan dapat mengaplikasikannya dalam pemecahan masalah.

Dari keseluruhan rangkaian pembelajaran dalam penelitian ini terdapat beberapa kendala, yaitu adanya siswa yang kurang aktif dalam mengerjakan soal, siswa yang tidak bisa sama sekali tentang materi lingkaran, siswa yang mempunyai perasaaan takut salah dalam mengerjakan soal. Dari pendekatan pembelajaran yang digunakan, menurut guru bidang studi matematika sudah 


\section{Magfirotul Mufida, Sholahuddin Al Ayubi, dan Tri Novita Irawati \\ E ISSN 2615-0697 dan P ISSN 2622-8149 \\ $108-114$}

bagus hal ini terlihat dari hasil wawancara dengan guru bidang studi yang mengatakan bahwa sebenarnya pembelajaran matematika dengan metode TSTS mampu meningkatkan keaktifan dan hasil belajar siswa. Selain itu TSTS ini menuntut guru untuk lebih memahami konsep matematika secara lebih mendalam.

Berdasarkan penelitian di SMP Nusantara ketuntasan hasil belajar yang diperoleh dalam penelitian ini adalah mayoritas siswa merasa senang, aktif dan antusias selama mengikuti pembelajaran. Aktivitas belajar siswa pada siklus I dengan persentase $73 \%$ dan pada siklus II dengan persentase $82 \%$, terjadi peningkatan aktivitas belajar siswa lebih baik. Peningkatan hasil belajar siswa pada siklus I diperoleh persentase $71 \%$ dengan ketuntasan klasikal sebesar $75 \%$ dan pada siklus II diperoleh persentase $85 \%$ dengan ketuntasan klasikal sebesar $75 \%$, sehingga dapat disimpulkan jika proses pembelajaran dengan menggunakan TSTS ini diterapkan dengan benar maka akan dapat meningkatkan hasil belajar yang memuaskan.

\section{KESIMPULAN DAN SARAN}

Berdasarkan hasil penelitian yang telah dilaksanakan dapat diambil kesimpulan sebagai berikut: 1) aktivitas belajar siswa selama pembelajaran dengan menggunakan strategi pembelajaran Kooperatif tipe Two Stay Two Stray dilihat pada lembar observasi aktivitas siswa mengalami peningkatan dari siklus I ke siklus II, hal tersebut ditunjukkan dengan kenaikan perolehan persentase aktivitas pada siklus I sebesar $73 \%$ dengan kriteria cukup dan pada siklus II sebesar $82 \%$ dengan kriteria baik. 2) Hasil belajar siswa selama pembelajaran dengan menggunakan strategi pembelajaran kooperatif tipe Two Stay Two Stray dilihat pada nilai hasil belajar siswa mengalami peningkatan dari siklus I ke siklus II. Hal tersebut ditunjukkan dengan kenaikan dari siklus I 71\% ke siklus II 85\% dengan kriteria baik. Berdasarkan hasil penelitian maka dengan kerendahan hati peneliti mengungkapkan saran sebagai antara lain: 1) Agar aktivitas belajar siswa meningkat maka penggunaan metode pembelajaran Kooperatif tipe Two Stay Two Stray dapat menjadi alternatif untuk digunakan oleh guru dalam pembelajarannya. 2) Agar pembelajaran dan hasil belajar siswa dapat meningkat, sebaiknya guru mengembangkan pembelajaran metode pembelajaran Kooperatif tipe Two Stay Two Stray. 
Magfirotul Mufida, Sholahuddin Al Ayubi, dan Tri Novita Irawati

E ISSN 2615-0697 dan P ISSN 2622-8149

$108-114$

\section{DAFTAR RUJUKAN}

A.M. Sudirman. 2011. Interaksi dan Motivasi Belajar Mengajar. Jakarta: Raja Grafindo Persada

Abdurrohman, Mulyono. 2003. Pendidikan bagi Anak Berkesulitan Belajar. Jakarta: Rineka Cipta.

Anita Lie. 2010. Cooperative Learning Mempraktikkan Cooperative Learning di Ruang-Ruang Kelas. Jakarta: Grasindo.

Depdiknas 2003, Undang-Undang RI No.20 tahun 2003. Tentang Sistem Pendidikan Nasional.

Hamalik, Oemar. 2008. Perencanaan Pengajaran Berdasarkan Pendekatan Sistem. Jakarta: Bumi Aksara.

Huda, Miftahul. 2011. Cooperative Learning. Yogyakarta: Pustaka Belajar.

Ma'rif, Samsul. 2012. Metode pembelajaran TSTS (Two Stay Two Stray). http://sam-edogawa.blogspot.com/2012/11/metode-pembelajaran-tsts-twostay-two-stray.html

Yusfy . 2010. Pengertian Aktivitas Belajar. http://id.shoong.com/socialsciences/education/2241185-pengertian-aktivitas-belajar/. 